\title{
Weaver-Tremblay Prize
}

\section{Anthropology in the Court and Tribunal}

Bruce Granville Miller

University of British Columbia

Tam speaking from unceded, ancestral Coast Salish lands in Vancouver, 1 the home of the Musqueam, Squamish, and Tsleil-Waututh. My thanks to President Mulholland, Past President Doyon, and members of the CASCA executive for all of their work regarding this award, and to Tad McIlwraith and Beth Finnis of the CASCA conference organizing committee. Thanks also to those who submitted the materials for the award, particularly Tad McIlwraith and Molly Malone.

As an immigrant to Canada thirty-one years ago, it is a particular pleasure to be here today receiving this award, which has so many notable alumni, many of whom I know. I didn't know Sally Weaver or Marc-Adélard Tremblay, but I am delighted to receive an award in their names. Canadian anthropology, as this prize recognizes, has long held a special concern for using anthropology to the benefit of society and to tackle difficult dilemmas. Canadian anthropology and CASCA, and my department at UBC, have been wonderful homes for me. My most sincere thanks to the Canadian and other anthropologists gathered online today, including my Brazilian friends. There is a different sort of opportunity structure here in Canada which often enables people's talents to be cultivated, unlike the hyper-capitalism to our south which so often results in overlooking and failing to cultivate their young. That is, to me, a distinct difference between countries and anthropologies.

One other note about Canada: there were wonderful scholars here long before I showed up, and a great group behind my generation of "young old people," including Thomas McIlwraith, Jane McMillan, Brian Thom, Bill Angelbeck, Molly Malone, Dave Schaepe, Morgan Ritchie, Brenda Fitzpatrick, 
and many others. These younger people are inspirational to me and fun to be with. And, there is a highly intelligent still younger generation with a nose for finding and working on issues that count, including Riley Bertoncini, starting at McGill. There is every reason for optimism for our discipline.

I recall listening to Peter Stephenson's eloquent talk at this event some years ago. That was a good model. I got some advice about giving this talk. My brother told me to make the talk funny. Medical anthropologist Bill McKellin, by way of warning, told me that Canadians don't like people talking about themselves. In total disregard of their advice, I'm shooting for meandering and personal. I want to talk about the anthropology I have deployed in the various legal issues I've been involved in over the last decades and the Canadians who produced this anthropology. I recently wrote an ethnography of court and tribunal rooms, tentatively titled Inside and Outside the Tribunal Hall: An Anthropologist Encounters Human Rights. I'm trying to make sense of the contributions anthropology and social science make in Indigenous legal processes and how these processes might be further transformed. It falls into the category of the anthropology of law. To do this, I situate my work at the intersection of the state and the Indigenous nations, sometimes a difficult place to be. Sherry Ortner (20I6) recently wrote about what she calls dark anthropology; anthropology that focuses on hard dimensions of social life (power, discrimination, inequality, and oppression) and the resultant depression and hopelessness. There is also, she says, the anthropology of the good, of the good life and happiness, morality, and ethics. And, a third sort of anthropology of the good-studies of resistance, activism, critique. Anthropology, she writes, needs studies of the good and the dark and resistance. My work encompasses this, I believe. I'll illustrate how.

First, though, I have recently been wondering how it is that I have spent most of my adult life involved in a broad range of Indigenous legal issues. I didn't set out to do this, and it started when Doreen Maloney, the grand-dame of the Upper Skagit Tribe of Indians, asked me, while I was doing dissertation research with her Nation in western Washington, to prepare to testify about fisheries in a phase of the treaty-rights case known as United States $v$ Washington. Also, she asked a bit later, would I please be the Early Childhood Educator (ECE) for the community? Certainly, I said, what will those activities involve? I continue to find answers to that question. I can say, though, that I've been pulled in because we are in a period when Indigenous peoples and communities have brought attention to a range of discriminatory practices and want the research capabilities we can bring. And sometimes communities want something else. 
Regarding the work as the ECE teacher - the anthropology of the good -I was trained in ECE work by a woman from another, nearby American Indian community, and then, walked daily through the reservation carrying a red bag loaded with children's books - and I went to all of the houses with children three or four years old. There I told them Skagit mythic stories - at the request of the tribal leader, and worked with them on pre-school activities. And gave their families books. Sometimes my work involved hopping games, a fact of which I am reminded when I am on that reservation. There might be no better way to get to know an Indigenous community than being an ECE teacher.

I live on what is called the Northwest Coast in the ethnographic literature, and spend time sitting in and living in Coast Salish longhouses, listening to the master orators in those communities. For that reason, I think of events like today as something like what Coast Salish call "work," or potlatch, in this case, concerning the acquisition of a new title. Community members are gathered, even those from beyond my UBC village, and at the conclusion, you will be convinced to accept this new claim, the Weaver-Tremblay Prize, or not. It is my and my families' (in this case, the CASCA executive) responsibility to do the behindthe-scenes work prior to this occasion - "you have, haven't you?" - to ensure that everyone is in agreement with this award. I hope you are. My speakers and I must show extended kin connections, and I will indeed make references to Julie Cruikshank, Dara Culhane, and others. And then, I must remind you of the values and practices of our community, handed down from our Elders. I intend to do that, a little. And, ordinarily you must be fed. But not on this occasion.

In pondering what happens in court rooms, law offices, tribal centres, on the water fishing, and on land hunting, I have filled notebooks with observations of legal processes that I and others are part of. My method is to write from the inside and witness the entirety of these processes. Sometimes this has been horrendous, the anthropology of the personal dark, to mutate Ortner's term, as when the right-hand man of the commissioner in the BC Missing Women's Commission of Inquiry told me in a private meeting that if I insisted on filing my report on systemic racism in policing in Vancouver, he would put me on the stand for two weeks and crucify me. My report was based on a thousand pages of internal documents given to me by the professional legal staff who asked me to do this study. The situation was highly threatening and my wife, partly in jest, wanted to know if we needed to change our phone number. The Commission report did not, in fact, consider systemic racism in the police force. 
But my experiences are also curious, let's call it the anthropology of the curious: two different judges have told me during court hearings that I am interesting and they would like to have a beer with me sometime. By the way, regarding drinking beer with judges; it is never good when a judge says this. It means they think my testimony is quaint and unnecessary folklore.

I've begun considering the implications of the various ways lawyers and legal officials have regarded my work and sometimes my "self" as a preliminary way of thinking about what the legal domain makes of anthropology. In expert testimony before the Yukon Supreme Court in 2019, the lawyer for the Yukon attempted to paint me as too old to know what is going on in the present. I made what she regarded as a telling point in my report to the court in referring to Dances with Wolves as a way of explaining the idea of noble/ignoble savages in western and discriminatory thought. It's from the I980s, she said, and I responded that it was a classic. Exactly, she retorted (Miller 2020).

A lawyer in a summation in another case depicted me as an "ivory tower" academic. He asked me in cross-examination if I was an academic. Yes, I responded, and in doing my job I have been in the field with Indigenous community members fishing, hunting, at tribal gatherings, funerals and other events, every one of the last forty years. He only remembered the "academic" part in his written report. It's a peculiar shadow we cast.

And, it is often painful watching legal processes go awry. A human rights case involving a former Indigenous faculty member denied tenure turned in part on her ability to drag several extra-large suitcases filled with documents out of her car, up the street, and into an elevator and then the tribunal offices every day of the hearings, and then to dig through these suitcases to find the documents she needed under the pressure of adverse cross-examination. And watching self-representing disputants who have somehow maneuvered through the labyrinth of paper work to get their case accepted by the human rights tribunal, and then have to muster their own cross-examination of witnesses, all while being hectored impatiently by the tribunal member and suffering demeaning commentary by the opposing legal counsel. My current thinking is that for Indigenous complainants in the human rights tribunal the process is inevitably traumatic and revisions of the tribunal must be undertaken with this in the forefront.

I regard much of what we do at present as something like trauma anthropology, but, still, with many high points. Some examples: 
Now for the scholarship, much of it Canadian, I have relied on my expert testimony in various cases: I have given testimony in several cases involving oral history as evidence. This came about because a legal historian pestered me for about six months, asking what anthropology was going to do following the ruling in Delgamuukw (1997) that oral history would have the same footing as written history, and, subsequently, the frantic efforts of the Crown to keep this evidence out. In trying to explain the nature of Indigenous oral history I have relied heavily on our colleague Julie Cruikshank, who worked with Tlingit/Athabascan women for many years and collectively worked out what became her books, including Life Lived Like a Story (1990) and later, Do Glaciers Listen? (2005). Crown arguments turned on notions of contamination - that oral historians who have read the history or anthropology of their own communities cannot be relied on or their evidence accepted because they may not be conduits of information intergenerationally. Or, if community myths contain world motifs they cannot contain local information. Both ideas are untrue, of course, and unnecessarily limiting, as Hornborg (2002), Cohen (1989) and others have pointed out. Cruikshank has helped move the field from the sterile search for facts, a perspective which allowed oral histories to be cherry-picked, excavated and reworked into a narrative convenient for the state. And, Cruikshank's work provided the counter-argument to the Crown's frequent contention that the way to understand oral traditions is this: "an oral tradition, by virtue of its orality, is a product of the present in which it is told, heard and recorded" (Von Gernet 20I8, I7). Cruikshank notes to the contrary that oral materials are anchored in the past but creatively engage the present ("the evolving recognition that oral tradition anchors the present in the past" (Cruikshank 1994, 408, 407). She and many have pointed to an emphasis on understanding the meaning or meanings, since, as these scholars note, oral traditions operate on multiple levels simultaneously.

My colleague Sonny McHalsie, Naxaxalhts, a cultural advisor to the Stó:lō Nation, and an oral historian, talked with me about these legal issues at my kitchen table. I told him about the Crown theory of contamination, which caused him to startle in disbelief. He, of course, reads everything about his community, as do other Indigenous oral historians of my acquaintance. Naxaxalhts told me in response: "When I read Duff [my predecessor at UBC] or Hill-Tout, I'm not reading what he wrote, but what the person who told him said. I'm not in Duff's mind, but that of the person who told him. I look at the filters" imposed by academics (Miller 20II, 97). Naxaxalhts clearly does not hold the view that 
Indigenous community intellectuals are waiting to be told their oral histories by anthropologists, which appears to be the Crown's position. This is certainly a good thing. These issues are contained in my book, Oral History on Trial (20II).

A related issue is how expert knowledge is entered into the legal domain. As you know, there are two categories of testimony; by lay people who cannot speak about events or processes they have not witnessed; and by expert witnesses who can draw on any relevant materials and make inferences. I argue in the book that oral traditions that can be demonstrated to persist over time might be regarded as similar to ancient documents, the legal doctrine whereby written materials that pass the test of time have a certain validity. And, similarly, Indigenous oral historians who are acclaimed and acknowledged by their communities might be regarded as experts for the purposes of testimony, perhaps with oral footnoting to their own predecessors. It would help remove anthropologists from the dubious position of hearing oral traditions and presenting them in court when the community members might be restricted. Canada has been a leader in giving oral materials a sound position in court, but this has prompted actions to undercut these materials. In any event, there are other things for anthropologists to do; plenty to do, besides conveying the content of oral traditions. Many Elders and community members have undertaken this function. The Indigenous Bar Association has worked with the Canadian federal judiciary to find solutions to the problems of Elder testimony, and oral histories, including the sense of mistreatment and injustice when Elders are subjected to adverse cross-examination.

A more recent engagement in Ontario litigation concerns the idea of deeptime oral history and the question: Are there oral historical materials which survive over long periods? The Indigenous litigants were relying on these oral histories. The Crown had taken the position in its report to the court in a recent case in which I participated that it is unlikely and that there is no science to support this idea. This is a case in which I consulted with the attorneys acting for the Indigenous litigants seeking treaty relief. Here I was delighted to inform the lawyers that, in fact, there was hard science on this topic (of which the Crown was unaware) produced by several scholars including the archaeologist Andrew Martindale of my own department. I want to try to get this right because Martindale and his colleagues engage concepts that are ordinarily beyond my scope of work, ideas such as Baysian statistics. These scholars are not simply matching up oral histories and archaeology, but rather, deploy normal science, 
to test. I'm going to read this abstract to a paper by Edinborough, Porčić, Martindale et al in Proceedings of the National Academy of Sciences of the United States of America (2017, 12436).

We rigorously test the historicity of indigenous Tsimshian oral records (adawx) using an extended simulation-based method [...] Second, we test the Tsimshian adawx accounts of an occupational hiatus in their territorial heartland ca. I,500-I,OoO years ago. We are unable to disconfirm the oral accounts. This represents the first formal test of indigenous oral traditions using modern radiocarbon modeling techniques.

Recall that the Crown argued that deep-time oral histories were improbable, perhaps impossible.

A related issue concerns Occam's razor, which the Crown argued mitigated against any real possibility of deep-time oral histories because it would involve multiple unlikely steps. However, Martindale pointed out elsewhere that Occam's Razor would point to the acceptance of these oral materials because the simplest explanation of their correspondence is that they are/concern the same event.

I would like to introduce another case, of a quite different sort, this one heard by the BC Human Rights Tribunal. In the 2005 case of Radek $v$ Henderson Development, Gladys Radek, a middle-aged woman of Tsimshian ancestry who lived in Native Housing across from the Tinseltown Mall in downtown Vancouver, was mistreated by security guards at the Mall. She found a lawyer, and brought a human rights case. The lawyer hired me to build a context for the tribunal to understand the situation. I examined the incidence reports and the training manual. Among other things, I pointed out that an emphasis on reporting "suspicious behavior" would differentially disadvantage Indigenous people in a society whose members have existing stereotyped and discriminatory perceptions. In this case, and others, I relied on the scholarship of Dara Culhane (1987) who has ably shown in her book on Alert Bay how discrimination in medical services disadvantages Indigenous people, and Liz Furniss (1999) who described what she called the "frontier thesis," that the white community of central British Columbia came to regard the Indigenous population there as the opposite of themselves, the people who they imagine industriously built the society. I also deployed sociologist Renisa Mawani's (20I0) studies of racialization and the creation of exclusionary zones in early Vancouver history, geographer Cole Harris' (2003) notion of the resettlement of British Columbia by the systematic removal of Indigenous people, and sociologist Elizabeth 
Comack's study of racialized policing. And much more good social science and history. The point in these cases is to make clear, in relatively simple language, what happens in the contact zone. I have learned, in examining the records of security guards, police, health professionals and others, that those who cannot theorize racism, cannot keep racism out of their records. In the Radek case, I found sketches of Indigenous people on the edges of hand-written incidence reports which exaggerate Indigenous people's stereotypical features; in police reports, regular references to street-entrenched women as whores and worse, and even in medical charting references to "addicts" and to casual assumptions about alcoholism in place of a professional assessment of health status. I am happy to say that the Radek case showed that anger on the part of complainants is a proper response to colonialism. My testimony showed that discrimination can arise in the absence of intent and can be demonstrated without statistical validation.

Another case illustrates the role of anthropology in litigation and our reliance on allied researchers who themselves borrow ethnographic methods from anthropology. This recent case was an inquest heard by the Yukon supreme court (Miller 2020), regarding a young Indigenous woman who died while being medevacked to Whitehorse, after a delay of many hours. I relied on the old-school ethnography of rural medical stations and the forms of discrimination faced by Indigenous people, scholarship produced by professor of nursing Annette Browne, Colleen Varcoe and others including my wife, anthropologically trained public health nurse Laraine Michalson, using ethnographic methods borrowed from anthropology. They wrote

...in health care [...] assumed 'cultural traits' are typically those identified as different from 'ours,' the unspoken comparison being made with the assumed dominant norm. From this narrow viewpoint, nurses and other health care providers often operate on the basis of erroneous assumptions about people who are assumed to be members of particular ethnocultural groups. Operating in this manner may cause nurses and others to overlook the most salient factors that are influencing people's health (2019, 30).

Further (Varcoe, Browne, and Michalson 2019, 30) “... culture is often given as the primary explanation for why certain people or populations experience various health, social, or economic problems. Research shows that health care providers frequently attribute people's social problems to their cultural characteristics." 
I did my part, too, in the Yukon hearing, explaining stereotyping and discrimination, both conscious and unconscious, intentional and otherwise, and the possibility of discriminatory behavior by people who otherwise held multicultural values. But I was excluded from commenting on the nursing notes because in a voir dire in which I could not participate an argument was made that I had no training in medicine. I don't, but the issue wasn't medical practice, but rather, note-taking. This is an example of thinning - of parsing anthropological knowledge to dilute the efficacy of our testimony. I've recently written about this because it is a near-constant occurrence in giving expert testimony, and demeans and diminishes our ability to clarify issues for the jurors.

Regarding Canadian health systems, these authors I just mentioned write: The Canadian health system has particular features, sometimes referred to as the dominant health care culture [...] health care providers working in the dominant health care culture often judge people negatively depending on their health practices (for example, for their failure to exercise or to stop smoking tobacco). They may also tend to value adherence or "compliance" with medical recommendations [...] However, the extent to which patients and their family members ascribe to the values of the dominant health care culture varies greatly. For some patients, the Western-style approach to history taking (asking questions in quick succession) is not part of their pattern of communication. For some, taking a prescription medicine required consultations with other family members (ibid.).

All of this work by these researchers is what I think of as useful anthropology. In the Yukon inquest case, the findings and recommendations by the jury precisely mirrored the perspective these nurse ethnographers had recorded and which I told the jury about, in writing and orally. In that inquest, the members of the jury asked me questions for about forty-five minutes. They were able to take a little time to ask, in their own way, questions about the nature of our society and of the circumstances which create discrimination and poor health outcomes. I told them that the deceased woman's community needed health practitioners who could provide culturally-informed care. The jury recommended that the community be given a nurse-practitioner.

Here is an instance of dark anthropology transformed into the anthropology of the good (recall again, Ortner's categories), heard before the BC Human Rights Tribunal. This case concerned a First Nations woman, Ms. Campbell, who, while 
out for a walk, noticed her son getting arrested, and in her efforts to find out what was happening and to hand him a cigarette, was dragged back about forty feet and tossed to the ground by police. In the process of preparing to testify in the case, I met for three and a half hours with Ms. Campbell. She regaled me with a cogent and powerful critique of the state, of the police, of society, and of colonialism. She didn't let me off the hook. It was a beautiful rant, which I mean in a positive way. It's helpful to be told of these matters by those concerned in a forceful way such as she did. The problem was that her fear of police was so great that I could not use my notes from the meeting and my new understanding of her particular situation in my testimony. The VPD demanded the notes under the legal principal of discovery but they were not turned over. She almost abandoned the case of discrimination accepted by the tribunal because of fear of future discrimination. It's something to think about as we consider whether tribunals meet the needs of Indigenous peoples.

She also interjected during the tribunal process, refusing to abide by conventional rules of decorum, all the while making her point about her treatment and discrimination more broadly. I wasn't sure how the tribunal member would respond. My experience with that tribunal, in witnessing and participating in a number of cases, was that she might be treated as a hostile and unreliable witness and therefore lose her case. She was not, and instead, was awarded \$20,00o for injuries to her dignity. I should also note that at the start of the hearing smudging took place in a room adjacent to the hearing room and an Elder gave a prayer in the hearing room itself. These are practices I have not seen previously in that tribunal. Sometimes it's the little details which hold importance. I argue that reforms of the human rights tribunal must begin by thinking of the symbolic violence and trauma the Indigenous people experience in bringing a case and in enduring the hearing itself, if they should be so lucky to get a case heard. Menzies listened while Vancouver Police, those who abused her, in testimony, demanded to know why they had to appear.

Not all of my work concerns human rights, treaty rights, or land claims and the ways in which these are conducted. One of my first anthropological endeavors concerns those communities of Indigenous peoples that do not have recognition by the state. In the mid I970s, when I lived in Washington state, a court ruled that the Puyallup Indians, as they officially call themselves, owned the Port of Tacoma, one of the major deep-water ports on the west coast. There was a lot of hostility in the public about this situation and the state put immense 
pressure on the tribe to sell their interest in the port. The tribal attorney told me that the tribe was not able to engage meaningfully with the state and I organized the first, and only, public debate with the tribe and the city and state.

Then, before the event, I found out there was another local entity, a tribe, the Steilacoom, which had existed before the state was created, but was not recognized as an American Indian tribe. I invited their representative to present their perspective on the port. But now I had new questions - who were these people and were there other groups in similar circumstances? With time, I met some of these other groups and began researching their backgrounds, eventually presenting research to a branch of the US federal government established to consider the issue of recognizing tribal groups and to Canadian authorities. There were dark elements of this work, too. In one case, I presented my study of Samish community cohesion and other features, as required under the recognition provisions, along with other materials submitted by the tribe. They were rejected, but their charismatic and imaginative leader, Kenny Hanson, tried out several approaches to gain support for his tribe. He declared war on the US and sought to have his people declared an endangered species. Those didn't work out but through the freedom of information act, his tribe was able to prove in an administrative law court that the US Department of the Interior had misrepresented my data and colluded against his tribe in the ruling against recognition. A new proceeding was ordered and, as hard to believe as this is, the same thing happened. At that point, a judge ordered the tribe recognized. Since then I've worked with tribes in the US and Canadian bands facing the same situation. I wrote a book, Invisible Indigenes (2003), about the situation of non-recognition world-wide. My argument is, in part, that communities, pushed historically into marginal areas such as mountains, today occupy landscapes which resource extraction companies now wish to exploit. The inconvenient "Indians" have been removed administratively, and in some cases, simply defined out of existence.

Since that book, new perspectives have found their place in scholarly and other debates. The literatures of resurgence and refusal don't necessarily envision state recognition as a good thing. These proponents want something better, more Indigenous, and less responsive to state definitions and practices. These are important aims. But I should say that I've worked with communities that see benefits in recognition. They have a sense of invisibility in their own homelands. On one occasion, a First Nations student in my course on oral history told 
me that I am, in her words, "a bad person" for my work with communities as expressed in Oral History on Trial. The incremental progress associated with legal proceedings such as the Yukon case or the Radek case didn't appeal to her. We can be said to paper over the normalization of the symbolic violence of our legal system by legitimizing the processes and legal rulings. I think of John Borrows' comment, however, regarding the presence of oral traditions in court "That besides challenging the law's underlying legitimacy it can simultaneously assert an alternative structure of legitimate normative order" (Borrows 200I, 26). The student might be right and, although I won't see it, I am interested in what the next forty years will bring.

Forty years ago, when I began engagement with Coast Salish peoples of Canada and the US, none of the tribes/bands had the community centres and programming they now offer - things such as legal services, child welfare, health care, social services and so on. Upper Skagit has become prosperous as a community, buying properties in their ancestral lands and establishing profitable businesses. They have become a major employer in their county. I understand that these developments do not describe the circumstances of many of the Indigenous peoples within Canada. But the image of the good persists: in 199I when the Stó:lō Nation contacted my department to ask for research help, Julie Cruikshank and I created a graduate ethnographic fieldschool resident in Stó:lō territory, living in a long house with Frank Malloway, Sieymchis. In that first meeting to discuss the field-school, held in a trailer, we met with the entire Stó:lō staff of about five. Today they have something like 350 staff members and a number of spec-built buildings. What will the next forty years bring? Some young scholars, such as Joey Weiss, a Canadian faculty member at Wesleyan College, are doing that in their emphasis on possible futures or how communities are choosing from among possible directions.

Bill McKellin told me to present a vision for anthropology in this talk. I thought that seemed like a poor idea for me, but something I would have to try. So, it is this: something I tell undergraduates: anthropology works well from the ground up. No one, or very few, are doing this kind of work at the university, and there is a lot to do from this perspective in contemporary Canada, Brazil, the United States, and elsewhere. Anthropology is an inherently interdisciplinary discipline and we can work with colleagues in archaeology, sociology, philosophy, nursing and other fields to point out how things work and might be reconceived. I am an advocate of plain language, as you heard here. The 
work by Dave Schaepe, Bill Angelbeck and colleagues (2017) on what might be called social work archaeology best exemplifies this. I have found repeatedly that the anthropology that works in court is often simple ideas; of kinship, exchange, orality, simple demographics, and so forth, ideas which might be heard and understood by the court. These are ideas one might encounter in a first-year course. Meanwhile, our ethnography practices have diffused to other fields, including, most successfully at UBC, nursing, but we need to keep providing the leadership in how ethnographic and other anthropological methods can be used to hold a mirror to society. A mirror on our work is good; bring on the anthropology of the good.

Thank you.

\section{Bruce Granville Miller,} University of British Columbia, bruce.miller@ubc.ca

\section{References Cited}

Borrows, John. 200I. "Listening for a Change: The Courts and Oral Tradition." Osgoode Hall Law Journal/Revue juridique d'Osgoode Hall 39 (I): I-38. https://digitalcommons. osgoode.yorku.ca/ohlj/vol39/issI/I.

Culhane, Dara. 1987. An Error in Judgement: The Politics of Medical Care in an Indian/White Community. Vancouver: Talon Books.

Cohen, David William. 1989. "The Defining and Undefining of Oral Tradition." Ethnohistory 36 (I): 9-18.

Comack, Elizabeth. 2012. Racialized Policing: Aboriginal People's Encounters with the Police. Halifax and Winnipeg: Fernwood Publishing.

Cruikshank, Julie. 1990. Life Lived Like a Story. Lincoln: University of Nebraska Press.

——. 1994. "Oral Tradition and Oral History: Reviewing Some Issues." Canadian Historical Review 75 (3): 404-418.

——. 2005. Do Glaciers Listen. Vancouver: UBC Press. 
Edinborough, Kevan, Marko Porčić, Andrew Martindale, Thomas Jay Brown, Kisha Supernant, and Kenneth M. Ames. 20I7. "Radiocarbon test for demographic events in written and oral history." Proceedings of the National Academy of Sciences of the United States of America II4 (47): 12,436-I2,44I.

Furniss, Elizabeth. 1999. The Burden of History: Colonialism and the Frontier Myth in a Rural Canadian Community. Vancouver: UBC Press.

Harris, Cole. 2003. Making Native Space: Colonialism, Resistance, and Reserves in British Columbia. Vancouver: UBC Press.

Hornborg, Anne-Christine. 2002. "'Readback' or Tradition? The Klusap Stories among Modern Canadian Mi'kmaq." European Review of Native American Studies I6 (I): 9-I6.

Mawani, Renisa. 20I0. Colonial Proximities: Crossracial Encounters and Juridical Truths in British Columbia, I87I-I92I. Vancouver: UBC Press.

Miller, Bruce Granville. 2003. Invisible Indigenes: The Politics of Nonrecognition. Lincoln and London: University of Nebraska Press.

- - 20II. Oral History on Trial: Recognizing Aboriginal Narratives in the Courts. Vancouver: UBC Press.

Ortner, Sherry B. 20I6. "Dark anthropology and its others: Theory since the eighties." Hau: Journal of Ethnographic Theory 6 (I). https://doi.org/IO.I43I8/hau6.I.oo4.

Prince, Amber. 2020. Virtual lecture to Anthropology 47I, UBC, 26 November.

Schaepe, David M., Bill Angelbeck, David Snook, and John R. Welch. 20I7. "Archaeology as Therapy: Connecting Belongings, Knowledge, Time, Place, and Well-Being." Current Anthropology 58 (4): 502-533. https://doi.org/IO.IO86/692985.

Varcoe, Colleen, Annette J. Browne, and Laraine Michalson. 20I9. Chapter 7, Substance Use and Health Assessment. In Physical Examination \& Health Assessment, Third Canadian Edition. edited by Carolyn Jarvis, Annette Browne, June MacDonaldJenkins, Marian Lucktar-Fluede, IIO-I23, Elsevier Canada.

\section{Decisions and Case Materials}

Delgamuukw v. British Columbia, [1997] 3 S.C.R. IoIo.

Menzies v. Vancouver Police Board (No. 2), 2019 BCHRT I28. (Menzies is a pseudonym).

Miller, Bruce Granville. 2020. Expert Report re: Blackjack Inquest, Supreme Court of Yukon Case No.: 15-Aoo9, I5 August. 
Radek v. Henderson Development (Canada) and Securiguard Services (No. 3), 2005 BCHRT 302.

United States v. Washington, 384 F. Supp. 312 (W.D. Wash. 1974).

Von Gernet, Alexander. 2018. Approaches to Oral History and Traditions and Suggested Applications to Matters Relating to Certain Treaty No. 4 Reserves. Report prepared for Attorney General of Canada in relation to Watson et al. v. HMTQ (Federal Court TD T-2153-0o) \& Bear et al. v. HMTQ (Federal Court TD T-2155-0o). 